\title{
When can we stop wearing masks? Agent-based modeling to identify when vaccine coverage makes nonpharmaceutical interventions for reducing SARS-CoV-2 infections redundant in indoor gatherings
}

Authors: Trevor S. Farthing ${ }^{1} \&$ Cristina $\operatorname{Lanzas}^{1 *}$

${ }^{1}$ North Carolina State University, Raleigh, North Carolina, USA

*Correspondence to Cristina Lanzas (Mailing Address: 1051 William Moore Dr., RB410,

Raleigh, NC 27606 | Email: clanzas@,ncsu.edu | Phone: 919-513-6202)

\section{Declarations of Interest: None}

Abstract: As vaccination efforts to combat the COVID-19 pandemic are ramping up worldwide, there are rising concerns that individuals will begin to eschew nonpharmaceutical interventions

14 for preventing SARS-CoV-2 transmission and attempt to return to pre-pandemic normalcy

15 before vaccine coverage levels effectively mitigate transmission risk. In the U.S.A., some governing bodies have already weakened or repealed guidelines for nonpharmaceutical

17 intervention use, despite a recent spike in national COVID-19 cases and majority population of unvaccinated individuals. Recent modeling suggests that repealing nonpharmaceutical

19 intervention guidelines too early into vaccine rollouts will lead to localized increases in COVID-

2019 cases, but the magnitude of nonpharmaceutical intervention effects on individual-level SARS-

21 CoV-2 infection risk in fully- and partially-vaccinated populations is unclear. We use a

22 previously-published agent-based model to simulate SARS-CoV-2 transmission in indoor

23 gatherings of varying durations, population densities, and vaccination coverage levels. By

24 simulating nonpharmaceutical interventions in some gatherings but not others, we were able to

25 quantify the difference in SARS-CoV-2 infection risk when nonpharmaceutical interventions 
26 were used, relative to scenarios with no nonpharmaceutical interventions. We found that

27 nonpharmaceutical interventions will often reduce secondary attack rates, especially during brief

28 interactions, and therefore there is no definitive vaccination coverage level that makes

29 nonpharmaceutical interventions completely redundant. However, the reduction effect on

30 absolute SARS-CoV-2 infection risk conferred by nonpharmaceutical interventions is likely

31 proportional to COVID-19 prevalence. Therefore, if COVID-19 prevalence decreases in the

32 future, nonpharmaceutical interventions will likely still confer protective effects but potential

33 benefits may be small enough to remain within "effectively negligible" risk thresholds.

34

35 Keywords: agent-based model, COVID-19, indoor transmission, nonpharmaceutical

36 interventions, SARS-CoV-2, vaccine 
medRxiv preprint doi: https://doi.org/10.1101/2021.04.19.21255737; this version posted April 27, 2021. The copyright holder for this preprint (which was not certified by peer review) is the author/funder, who has granted medRxiv a license to display the preprint in perpetuity.

It is made available under a CC-BY 4.0 International license.

Introduction

Global vaccine rollout to combat the Coronavirus Disease 2019 (COVID-19) pandemic is well underway, with at least different seven vaccines approved for distribution by different countries (WHO 2021). In the U.S.A., where three vaccines have been approved for distribution (CDC 2021a), 24.8\% of the population has been fully vaccinated against COVID-19 as of April $17^{\text {th }} 2021$ (CDC 2021b). Despite ongoing vaccine rollouts, as of April 17 th 2021 , there is an

43 indication that COVID-19 cases are surging in some U.S. states (NY Times 2021). In spite of

44 rising case numbers, several U.S. states have recently rescinded, or allowed to expire, policies mandating use of nonpharmaceutical intervention in public spaces, with seemingly no intention of reinstating them in the near future (State of Iowa 2021; State of Mississippi 2021; State of Texas 2021). Population-level epidemiological models of vaccine rollout effects on COVID-19 transmission suggest that discontinuing nonpharmaceutical intervention use early into the vaccination effort leads to a subsequent surge in COVID-19 cases and related hospitalizations and deaths (Gozzi et al. 2021; Moore et al. 2021).

The magnitude of nonpharmaceutical intervention effects on individual-level SARS-

52 CoV-2 infection risk in fully- and partially-vaccinated populations is unclear. This information is

53 crucial for identifying vaccination levels at which it would be appropriate to scale-back

54 guidelines for nonpharmaceutical interventions, as it would allow governing bodies to base

55 policies on concrete risk estimates. The United States Centers for Disease Control and

56 Prevention (CDC) has updated guidelines on safe gathering protocols, recommending that groups

57 of fully-vaccinated people can now safely interact amongst themselves, or with small groups of

58 unvaccinated people at low risk for developing severe COVID-19, without utilizing any

59 nonpharmaceutical Severe Acute Respiratory Syndrome Coronavirus 2 (SARS-CoV-2) 
medRxiv preprint doi: https://doi.org/10.1101/2021.04.19.21255737; this version posted April 27, 2021. The copyright holder for this preprint (which was not certified by peer review) is the author/funder, who has granted medRxiv a license to display the preprint in perpetuity.

It is made available under a CC-BY 4.0 International license .

transmission interventions (e.g., face coverings, 2-m social distancing, etc.) (CDC 2021c).

However, the guidelines also recommend to continue avoiding medium to large gatherings, and the use of nonpharmaceutical interventions in public and when gathering with unvaccinated individuals. This caution stems from the incomplete knowledge of vaccine effectiveness across different populations, their effects on transmission, and the potential change on vaccine effectiveness caused by the emergence of new SARS-Cov-2 variants.

The problem with citing vaccination efforts as a justification for discontinuing nonpharmaceutical interventions is twofold. First and foremost, the majority of the U.S. population is not yet fully vaccinated (CDC 2021b), and therefore presumably has little-to-no immunity from SARS-CoV-2 infections. Secondly, while there is growing evidence that these vaccines reduce SARS-CoV-2 infection risk in addition to COVID-19 incidence, vaccines may not confer complete immunity or block transmission (Hall et al. 2021; Lipsitch \& Kahn 2021; Yellen et al. 2021). Data suggest that the BNT162b2 mRNA vaccine (i.e., the vaccine developed by Pfizer-BioNtech) may be $\approx 72 \%$ effective at preventing laboratory-confirmed SARS-CoV-2 infections after a single dose, and $\approx 86-92 \%$ two weeks following the second dose (Hall et al. 2021; Yellen et al. 2021). Furthermore, this vaccine may reduce viral loads, a potential proxy for infectiousness, in infected individuals by 3-4 times (Levine-Tiefenbrun et al. 2021). Less information is available on the ability of the other two vaccines approved for U.S. distribution to reduce SARS-CoV-2 infections, but Lipsitch \& Kahn (2021) do estimate that mRNA-1273 (i.e., the vaccine developed by Moderna and NIAID) can reduce individual-level infection risk by at least $61 \%$ following the first dose. Despite potentially-high infection-reduction efficacies, without vaccines that confer complete immunity from infection or prevent transmission from infectious individuals, it will be difficult to halt SARS-CoV-2 circulation in the population 
medRxiv preprint doi: https://doi.org/10.1101/2021.04.19.21255737; this version posted April 27, 2021. The copyright holder for this preprint (which was not certified by peer review) is the author/funder, who has granted medRxiv a license to display the preprint in perpetuity.

It is made available under a CC-BY 4.0 International license.

83 through vaccination efforts alone (Gozzi et al. 2021; Moore et al. 2021). Considering that most

84 people also have yet to be fully vaccinated, guidelines that advocate phasing out

85 nonpharmaceutical interventions during interpersonal interactions may be premature at this time.

86 In Farthing \& Lanzas (2021), we described an agent-based model (ABM) for simulating

87 indoor respiratory pathogen transmission. We previously used this model to quantify effects of

88 nonpharmaceutical interventions on reducing SARS-CoV-2 transmission risk during an indoor

89 superspreading event (Farthing \& Lanzas 2021). Here, we use it to simulate SARS-CoV-2

90 transmission in indoor gatherings of varying durations, population densities, and proportional

91 vaccination coverage. By simulating nonpharmaceutical interventions in some gatherings but not

92 others, we were able to quantify the difference in SARS-CoV-2 infection risk when

93 nonpharmaceutical interventions were used in conjunction with vaccination efforts, relative to

94 scenarios with no nonpharmaceutical interventions. Using these data, we demonstrate how

95 interested parties can easily estimate the potential reduction in SARS-CoV-2 infection risk

96 attributable to nonpharmaceutical interventions, and try to answer the question: "at what point

97 during vaccine rollout are gatherings without non-pharmaceutical measures safe?"

99 Methods

100 We used the ABM we first described in Farthing \& Lanzas (2021) to simulate the effect

101 of increasing vaccination coverage and nonpharmaceutical interventions on SARS-CoV-2

102 transmission risk during indoor gatherings. The simulation input levels and parameter values we

103 used are given in Table 1. We made the assumptions that any infectious individuals at gatherings

104 would be asymptomatic because symptomatic people would consciously decide to stay away,

105 and that no one with partial immunity exists within the group of attendees. Vaccinated people 
medRxiv preprint doi: https://doi.org/10.1101/2021.04.19.21255737; this version posted April 27, 2021. The copyright holder for this preprint (which was not certified by peer review) is the author/funder, who has granted medRxiv a license to display the preprint in perpetuity.

It is made available under a CC-BY 4.0 International license .

106 had a fixed probability of becoming completely immune to SARS-CoV-2 infection (Table 1),

107 and those that did not become immune remained susceptible to infection (i.e, 'all-or-nothing'

108 vaccine). Finally, we only simulated use of cloth face coverings, rather than notably more-

109 effective masks like N95s, because we make the assumption that the majority of Americans have

110 ready access to, and are more-likely to use cloth masks.

111 All simulations were carried out within the open-source modeling software, NetLogo

112 (Ver. 6. 1. 1 - Wilensky 1999). We executed a factorial simulation run in the NetLogo

113 BehaviorSpace using our specified input levels, and ran 200 simulations replicates of each

114 parameter set combination when the nonpharmaceutical interventions were included and when

115 they were not. We ran these factorial combination sets separately in order to save computation

116 time as there were two inputs (i.e., mask efficacy, attempted social distance) that only changed

117 when nonpharmaceutical interventions were simulated. We ultimately produced 1,612,800

118 simulations without nonpharmaceutical interventions, and 9,676,800 including them (i.e.,

$11911,289,600$ total simulations). We recorded the number of susceptible individuals infected in

120 each simulation, and aggregated this information into a single data set prior to analysis.

121 We reported the mean probability of observing $\geq 1$ successful infection event(s) and

122 mean secondary attack rates in indoor gatherings when an asymptomatic person was also in

123 attendance across factorial combinations of "between-group comparison" variables (Table 1).

124 Secondary attack rates here were calculated by dividing the number of people that were infected

125 at the gathering by the number of "healthy" people at the start of the gathering, and can also be

126 considered to be the individual-level probability of a previously healthy attendee being infected

127 at the gathering. To assess the difference between protection conferred by the simultaneous

128 deployment of pharmaceutical and nonpharmaceutical interventions, versus use of only 
medRxiv preprint doi: https://doi.org/10.1101/2021.04.19.21255737; this version posted April 27, 2021. The copyright holder for this preprint (which was not certified by peer review) is the author/funder, who has granted medRxiv a license to display the preprint in perpetuity.

It is made available under a CC-BY 4.0 International license .

129

130

131 a logit link function to map (0,1) values (Ferrari \& Cribari-Neto 2004). The specific model is 132 given by:

133

nonpharmaceutical interventions, we first smoothed the observed mean secondary attack rates $(\mu)$ by fitting them to a beta regression model with a fixed unknown precision parameter, $\phi$ using

$$
\begin{gathered}
\ln \left(\frac{\mu}{1-\mu}\right)(\phi)=(\phi) \beta_{0}+\beta_{1}(\text { Gathering duration })+\beta_{2}(\text { Intervention level })+ \\
\beta_{3}(\text { Vaccine coverage })+\beta_{4}(\text { Vaccine efficacy })+\beta_{5}(\text { Vaccine coverage } * \text { Vaccine efficacy }),
\end{gathered}
$$

where "Intervention level" is a categorical variable containing the following mutually-exclusive levels: "cloth face masks \& vaccination," "cloth face masks \& 2-m social distancing \& vaccination," and "vaccination only." Additionally, "Vaccine efficacy" here refers to the ability of vaccines to induce complete immunity to infection. "Vaccine coverage" and "Vaccine efficacy" are given in terms of decimal percent, not percentage points (e.g., 0.1 , not 10\%).

Because beta regression models assume all dependent variable values fall between 0 and 1 , we used the data transformation procedure described by (Cribari-Neto \& Zeiles, 2010) to reconstruct our proportion data without these extremities prior to model fitting. We used the pseudo- $\mathrm{R}^{2}$ calculation procedure given by Ferrari \& Cribari-Neto (2004) to assess the goodness of fit for our regression model.

After fitting our data, we used the regression model to predict the mean secondary attack rates during a 60-minute gathering with a single asymptomatic person in attendance across the complete factorial combination of covariate inputs described in Table 2 . We report the difference between predicted values when all interventions (i.e., cloth face masks \& 2-m social distancing \& vaccination) are utilized, and predicted values assuming vaccinations are the only interventions. All analyses and plotting were carried out using functions from the "betareg" 
medRxiv preprint doi: https://doi.org/10.1101/2021.04.19.21255737; this version posted April 27, 2021. The copyright holder for this preprint (which was not certified by peer review) is the author/funder, who has granted medRxiv a license to display the preprint in perpetuity.

It is made available under a CC-BY 4.0 International license .

152 (Ferrari \& Cribari-Neto 2004) and "ggplot2" (v. 3.3.2, Wickham 2016) R packages, respectively, 153 in RStudio (v. 1.1.463, RStudio Team, Boston, MA) (RStudio Team 2018) running R (v. 3.6.2, R

154 Foundation for Statistical Computing, Vienna, Austria) (R Core Team 2020).

\section{Results \& Discussion}

We found that the probability of $\geq 1$ successful transmission event generally increased

159 is highly sensitive to within-room population density (Farthing \& Lanzas 2021). We observed 160 that at low population densities and/or short-duration gatherings, the use of nonpharmaceutical

161 interventions can significantly reduce the probability of successful transmission. Furthermore, it

162 is clear that at low population densities, 2-m social distancing confers additional protective

163 effects when used in conjunction with cloth face coverings, even during relatively-long duration

164 gatherings. This is consistent with what we observed when we used the same ABM to directly

165 compare the effectiveness of varied nonpharmaceutical interventions to prevent SARS-CoV-2

166 transmission during a superspreading event (Farthing \& Lanzas 2021). We found that cloth face

167 masks alone conferred few protective effects in long-duration gatherings.

168 The probability of transmission events occurring was unlikely to reach $\approx 0 \%$ outside of

169 scenarios with low population density and multiple nonpharmaceutical interventions, or $\geq 95 \%$

170 vaccine coverage and vaccines that were $100 \%$ effective at preventing infections. Given that 1 )

171 current estimates place SARS-CoV-2 vaccine efficacies against infection between 60-90\% (Hall

172 et al. 2021; Lipsitch \& Kahn 2021; Yellen et al. 2021), 2) historical precedence suggesting adult

173 populations will fall well short of these high vaccination levels (Applewhite et al. 2020; CDC

174 2020), and 3) the difficulty government institutions have had enforcing nonpharmaceutical 
medRxiv preprint doi: https://doi.org/10.1101/2021.04.19.21255737; this version posted April 27, 2021. The copyright holder for this preprint (which was not certified by peer review) is the author/funder, who has granted medRxiv a license to display the preprint in perpetuity.

It is made available under a CC-BY 4.0 International license .

175 intervention policies (Jacobs \& Ohinmaa 2020; Pedersen \& Favero 2020), it is unlikely that these

176 scenarios will be representative of average real-world gatherings. Moreover, in 60-min gathering

177 scenarios, the probability of $\geq 1$ successful transmission event occurring is relatively high even

178 when gathering attendees utilize nonpharmaceutical interventions and most are vaccinated.

The probability that $\geq 1 \mathrm{SARS}-\mathrm{CoV}-2$-positive individual is in attendance at a gathering

180 can be calculated as

$$
1-(1-p)^{n}
$$

182 where $p$ is the local COVID-19 prevalence, and $n$ is the number of people at the gathering

183 (Chande et al. 2020). The prevalence of infectious cases ( $p$ ) can be highly uncertain because of

184 the variable testing effort across time and space, but it can be estimated by assuming that any

185 SARS-CoV-2-positive individuals are infectious at time of testing and will remain infectious for

186 a given period of time. Additionally, ascertainment bias can be factored in. The probability that a

187 given individual will be infected at a gathering is then

$$
\left(1-(1-p)^{n}\right) q_{i}
$$

189 where $q_{i}$ is the probability that individual $i$ will be infected given exposure to an asymptomatic

190 individual at the gathering. Effectively, what we report in Fig. 2 are estimates of $q_{i}$ under

191 different circumstances. Our findings suggest that cloth-based mask use, with or without 2-m

192 social distancing, often does not confer significant protective effects during long-duration

193 gatherings (Fig. 2), we have also shown that implementing these nonpharmaceutical

194 interventions can reduce overall transmission probability (Fig. 1) and secondary attack rates (Fig.

1952 , Table 3) during brief interactions or gatherings with relatively-few people (e.g., fewer than 10

196 people, the limit for indoor and/or outdoor social gatherings enforced by some U.S. states

197 (MultiState 2021)). This effectively means that strict guidelines for continued nonpharmaceutical 
medRxiv preprint doi: https://doi.org/10.1101/2021.04.19.21255737; this version posted April 27, 2021. The copyright holder for this preprint (which was not certified by peer review) is the author/funder, who has granted medRxiv a license to display the preprint in perpetuity.

It is made available under a CC-BY 4.0 International license .

198 intervention use will likely help to mitigate SARS-CoV-2 spread, and therefore COVID-19

199 incidence, for as long as these policies are in effect.

As vaccine coverage increases, the question now becomes "how much elevated risk is

201 acceptable in the absence of nonpharmaceutical interventions?" If we let $q_{i}^{\prime}$ denote the

202 probability that individual $i$ will be infected given exposure to an asymptomatic individual at a

203 gathering where no nonpharmaceutical interventions were in place, and $q_{i}^{*}$ denote the probability

204 that individual $i$ will be infected given exposure to an asymptomatic individual at a gathering

205 where some level of nonpharmaceutical interventions were in place, then the relative effect of

206 nonpharmaceutical interventions on reducing infection risk is equal to

$$
\frac{q_{i}^{*}}{q_{i}^{\prime}} * 100 \%
$$

By quantifying covariate effects in our beta-regression model, we provide interested parties with a formula that can be used to quickly determine generalized $q_{i}^{\prime}$ or $q_{i}^{*}$ values, without

210 the need for running a large number of simulations. Due to the logit link function we used, the

211 mean secondary attack rates in our ABM simulations $(\mu)$ can be predicted using the equation

$\mu=\frac{e^{\left.\beta_{0}+\beta_{1} \text { (Gathering duration }\right)+\beta_{2}(\text { Intervention level })+\beta_{3}(\text { Vaccine coverage })+\beta_{4}(\text { Vaccine efficacy })+\beta_{5}(\text { Vaccine coverage } * \text { Vaccine efficacy })}}{1+e^{\left.\left.\beta_{0}+\beta_{1} \text { (Gathering duration }\right)+\beta_{2} \text { (Intervention level }\right)+\beta_{3}(\text { Vaccine coverage })+\beta_{4}(\text { Vaccine efficacy })+\beta_{5}(\text { Vaccine coverage } * \text { Vaccine efficacy })}}$

215 (Ferrari \& Cribari-Neto 2004). Our regression model had a pseudo-R ${ }^{2}$ of 0.37 . Given the number

216 of stochastic processes in our ABM and the variability purposely introduced into simulations

217 (Table 1), we believe the explanatory power of the model is acceptable for our purposes here.

218 Assuming mean population-level vaccine efficacies of $60 \%$ and $80 \%$, which we believe are

219 conservative estimates for U.S.-approved vaccine efficacies, our regression model consistently 
medRxiv preprint doi: https://doi.org/10.1101/2021.04.19.21255737; this version posted April 27, 2021. The copyright holder for this preprint (which was not certified by peer review) is the author/funder, who has granted medRxiv a license to display the preprint in perpetuity.

It is made available under a CC-BY 4.0 International license .

220 predicts that secondary attack rates decrease by $55-58 \%$ when attendees utilize cloth masks and

221 2-m social distancing, regardless of gathering duration (Fig. 3). However, it is important to

222 reiterate that here we estimate the probability or infection given contact with an infectious

223 individual at a gathering $\left(q_{i}\right)$ and comment on the relative risk difference attributable to

224 intervention use. This should not be confused with the absolute risk of becoming infected at a

225 gathering (see Equation 3). We demonstrate the difference in Figure 4, which is a simplistic

226 example intended to show that even at relatively high COVID-19 prevalence levels, 20 people

227 gathering indoors for 60 minutes have a substantially-lower individual-level risk of SARS-CoV-

2282 infections than is suggested by $q_{i}$ alone. Though predicting intervention effects on community-

229 level COVID-19 prevalence and infection-related events (e.g., symptom-onset, mortality, or

230 hospitalization) is outside the scope of our model, our simulations do suggest that secondary

231 attack rates are negatively correlated with vaccine coverage. Given that we expect local COVID-

23219 prevalence to eventually follow similar trends (Gozzi et al. 2021), the relative impact of

233 nonpharmaceutical interventions on infection risk reduction will likely decrease over time as

234 vaccine rollouts continue.

235 In addition to being unable to comment on community-level infection metrics, there are a

236 few other limitations associated with our results that we must acknowledge. Aside from the

237 ABM design limitations outlined in Farthing et al. (2021), we make a number of assumptions in

238 our simulations. Most of these assumptions are directly tied to our parameter space detailed in

239 Table 1, and include such things as: in simulated gatherings only one asymptomatic individual

240 was in attendance, no individuals wear masks with exposure-reduction efficacies $>50 \%$ and

241 therefore we are not simulating the use of N95 or similar masks, and there is no simulated

242 forced-air ventilation or infectious individuals that produce superspreader-level of contaminated 
medRxiv preprint doi: https://doi.org/10.1101/2021.04.19.21255737; this version posted April 27, 2021. The copyright holder for this preprint (which was not certified by peer review) is the author/funder, who has granted medRxiv a license to display the preprint in perpetuity.

It is made available under a CC-BY 4.0 International license .

243 aerosols (e.g., 970 quanta (Miller et al. 2020)). Additionally, we do not simulate activity-specific

244 behaviors and individuals in our simulations were unmoving. Finally, we based the

245 infectiousness of asymptomatic individuals on the estimate given by Buonanno et al. (2020) (i.e.,

246142 quanta/hr), and to relate this estimate to ABM parameters we used the linear model

247 described in Farthing et al. (2021). However, this parameterization procedure may have over-

248 inflated virion transmissibility in certain scenarios because quanta-estimates are room-size

249 specific, and the Farthing et al. (2021) linear model was based on simulations of gatherings

250 within a relatively large room. In short, our results must be viewed through the lens of simulated

251 world parameters and behaviors, and likely will not wholly reflect all variability that may exist in

252 real-world transmission events. This is very common for ABM-based studies however, and we

253 feel that our model is sufficiently accurate to highlight general trends in indoor SARS-CoV-2

254 transmission and infection risk.

256 Conclusions

We found that nonpharmaceutical interventions will often reduce secondary attack rates,

258 especially during brief interactions, and therefore there is no definitive vaccination coverage

259 level that makes nonpharmaceutical interventions completely redundant. However, the beneficial

260 effect on absolute SARS-CoV-2 infection risk reduction conferred by nonpharmaceutical

261 interventions used during indoor gatherings is likely proportional to COVID-19 prevalence.

262 Therefore, if U.S. COVID-19 prevalence decreases in the future, nonpharmaceutical

263 interventions will likely still confer protective effects, but any potential benefits may be small

264 enough to remain within "effectively negligible" risk thresholds. 
medRxiv preprint doi: https://doi.org/10.1101/2021.04.19.21255737; this version posted April 27, 2021. The copyright holder for this preprint (which was not certified by peer review) is the author/funder, who has granted medRxiv a license to display the preprint in perpetuity.

It is made available under a CC-BY 4.0 International license.

\section{Acknowledgments}

This work was partially supported by CDC U01CK000587-01M001 and R35GM134934.

\section{Author Contributions}

Trevor Farthing led the model creation, data analysis, and manuscript writing, but both

271 authors conceived the ideas presented herein, contributed to model development and writing

272 efforts, and gave final approval for publication. Cristina Lanzas secured the funding.

273

Data availability

275

We first made our ABM publicly available for download in Farthing et al. (2021). The

current iteration can be downloaded from the Lanzas lab's github repository at

277 https://github.com/lanzaslab/droplet-ABM.

278

279

\section{References}

280 1. Adams WC. Measurement of breathing rate and volume in routinely performed daily

281 activities. 1993. Final Report, Contract No. A033-205. California Air Resources Board,

282 Sacramento, CA, USA.

283 https://ww2.arb.ca.gov/sites/default/files/classic//research/apr/past/a033-205.pdf.

284 2. Applewhite A, Stancampiano FF, Harris DM, Manaois A, Dimuna J, Glenn J, Heckman MG,

285 Brushaber DE, Sher T, \& Valery JR. (2020). A retrospective analysis of gender-based

286 difference in adherence to influenza vaccination during the 2018-2019 season. J Prim Care

287 \& Commun Heal 11:1-6. https://doi.org/10.1177\%2F2150132720958532. 
medRxiv preprint doi: https://doi.org/10.1101/2021.04.19.21255737; this version posted April 27, 2021. The copyright holder for this preprint (which was not certified by peer review) is the author/funder, who has granted medRxiv a license to display the preprint in perpetuity.

It is made available under a CC-BY 4.0 International license .

288

289

290

291

292

293

294

295

296

297

298

299

300

301

302

303

304

305

306

307

308

309

3. Buonanno G, Stabile L, \& Morawska L. (2020). Estimation of airborne viral emission: quanta emission rate of SARS-CoV-2 for infection risk assessment. Environ Internat 141:105794. https://doi.org/10.1016/j.envint.2020.105794.

4. Castillo JE, \& Weibel JA. (2018). A point sink superposition method for predicting droplet interaction effects during vapor-diffusion-driven dropwise condensation in humid air. Int $J$ Heat Mass Trans 118:708-719. https://doi.org/10.1016/j.ijheatmasstransfer.2017.11.045.

5. Chande A, Lee S, Harris M, Nguyen Q, Beckett SJ, Hilley T, Andris C, \& Weitz JS. (2020). Real-time, interactive website for US-county-level COVID-19 event risk assessment. Nat Hum Behav. 4:1313-1319. https://doi.org/10.1038/s41562-020-01000-9.

6. Cribari-Neto F, Zeileis A. (2010). Beta regression in R. J Stat Soft. 34(2):1-24. https://doi.org/10.18637/jss.v034.i02.

7. Das SK, Alam J, Plumari S, Greco V. (2020) Transmission of airborne virus through sneezed and coughed droplets. Phys Fluids. 32:097102. https://doi.org/10.1063/5.0022859.

8. van Doremalen N, Bushmaker T, Morris DH, Holbrook MG, Gamble A, Williamson BN, Tamin A, Harcourt JL, Thornburg NJ, Gerber SI, Lloyd-Smith JP, de Wit E, \& Munster VJ. (2020). Aerosol and surface stability of SARS-CoV-2 as compared with SARS-CoV-1. N Engl J Med 2020(382):1564-1567. https://doi.org/10.1056/NEJMc2004973.

9. Farthing TS, \& Lanzas C. (2021). Assessing the efficacy of interventions to control indoor SARS-Cov-2 transmission: an agent-based modeling approach. Preprint available at: https://doi.org/10.1101/2021.01.21.21250240.

10. Ferrari SLP, Cribari-Neto F. (2004). Beta regression for modelling rates and proportions. J Appl Stat. 31(7): 799-815. https://doi.org/10.1080/0266476042000214501. 
medRxiv preprint doi: https://doi.org/10.1101/2021.04.19.21255737; this version posted April 27, 2021. The copyright holder for this preprint (which was not certified by peer review) is the author/funder, who has granted medRxiv a license to display the preprint in perpetuity.

It is made available under a CC-BY 4.0 International license.

310 11. Fryar CD, Kruszon-Moran D, Gu Q, \& Ogden CL. (2018). Mean body weight, height, waist

311 circumference, and body mass index among adults: United States, 1999-2000 through 2015-

312 2016. National Health Statistics Reports, No. 122. United States National Center for Health

313 Statistics, Hyattsville, MD, USA. https://stacks.cdc.gov/view/cdc/61430.

314 12. Gozzi N, Bajardi P, \& Perra N. (2021). The importance of non-pharmaceutical interventions

315 during the COVID-19 vaccine rollout. Preprint available at:

316 ttps://doi.org/10.1101/2021.01.09.21249480.

317 13. Hall VJ, Foulkes S, Saei A, Andrews N, Oguti B, Charlett A, Wellington E, Stowe J, Gillson

318 N, Atti A, Islam J, Karagiannis I, Munro K, Khawam J, The Siren Study Group, Chand MA,

319 Brown C, Ramsey ME, Bernal JL, \& Hopkins S. (2021). Effectiveness of BNT162b2 mRNA

320 vaccine against infection and COVID-19 vaccine coverage in healthcare workers in England,

321 multicentre prospective cohort study (the SIREN Study). Preprint available at:

322 https://dx.doi.org/10.2139/ssrn.3790399.

323 14. Jacobs P, \& Ohinmaa AP. (2020). The enforcement of statewide mask wearing mandates to

324 prevent COVID-19 in the US: an overview. F1000Res 9:1100.

325 https://dx.doi.org/10.12688\%2Ff1000research.25907.1.

326 15. Kwon S-B, Park J, Jang J, Cho Y, Park D-S, Kim C, Bae G-N, \& Jang A. (2012). Study on

327 the initial velocity distribution of exhaled air from coughing and speaking. Chemosphere

328 87(11):1260-1264. https://dx.doi.org/10.1016/j.chemosphere.2012.01.032.

329 16. Levine-Tiefenbrun M, Yelin I, Katz R, Herzel E, Golan Z, Scheiber L, Wolf T, Nadler V,

330 Ben-Tov A, Kuint J, Gazit S, Patalon T, Chodick G, \& Kishony R. (2021). Decreased SARS-

331 CoV-2 viral load following vaccination. Preprint available at:

332 https://doi.org/10.1101/2021.02.06.21251283. 
medRxiv preprint doi: https://doi.org/10.1101/2021.04.19.21255737; this version posted April 27, 2021. The copyright holder for this preprint (which was not certified by peer review) is the author/funder, who has granted medRxiv a license to display the preprint in perpetuity.

It is made available under a CC-BY 4.0 International license .

333 17. Lipsitch M, \& Kahn R. (2021). Interpreting vaccine efficacy trial results for infection and

334 transmission. Preprint available at: https://doi.org/10.1101/2021.02.25.21252415.

335 18. Miller SL, Nazaroff WW, Jimenez JL, Boerstra A, Buonanno G, Dancer SJ, Kurnitski J,

336 Marr LC, Morawska L, \& Noakes C. (2020). Transmission of SARS-CoV-2 by inhalation of

337 respiratory aerosol in the Skagit Valley Chorale superspreading event. Indoor Air 00:1-10.

$338 \quad$ https://doi.org/1010.1111/ina.12751.

339 19. Moore S, Hill EM, Tildesley MJ, Dyson L, \& Keeling M. (2021). Vaccination and non-

340 pharmaceutical interventions: when can the UK relax about COVID-19. Preprint available at:

$341 \quad$ https://doi.org/10.1101/2020.12.27.20248896.

342 20. MultiState. (2021). COVID-19 State and Local Policy Dashboard.

343 https://www.multistate.us/research/covid/public. [cited 2021 Apr 14].

344 21. O'kelly E, Pirog S, Ward J, Clarkson PJ. (2020). Ability of fabric face mask materials to

345 filter ultrafine particles at coughing velocity. BMJ Open 10(9):e039424.

346 http://dx.doi.org/10.1136/bmjopen-2020-039424.

347 22. Pedersen MJ, \& Favero N. (2020). Social distancing during the COVID-19 pandemic: who 348 are the present and future noncompliers. Public Admin Rev 80(5):805-814.

349 https://doi.org/10.1111/puar.13240.

350 23. R Core Team. (2020). R: A language and environment for statistical computing. R

351 Foundation for Statistical Computing, Vienna, Austria. https://www.R_project.org. [cited

$352 \quad 2021$ Mar 26].

353 24. RStudio Team. (2018). RStudio: integrated development Environment for r. RStudio Team,

354 Boston, Massachusetts, USA. http://www.rstudio.com. [cited 2021 Mar 2]. 
medRxiv preprint doi: https://doi.org/10.1101/2021.04.19.21255737; this version posted April 27, 2021. The copyright holder for this preprint (which was not certified by peer review) is the author/funder, who has granted medRxiv a license to display the preprint in perpetuity.

It is made available under a CC-BY 4.0 International license.

25. State of Iowa. (2021). Public health proclamation - 2021.02.05. https://governor.iowa.gov/sites/default/files/documents/Public\%20Health\%20Proclamation \% 20-\%202021.02.05.pdf. [cited 2021 Mar 26].

26. State of Mississippi. (2021). Executive order No. 1549. https://www.sos.ms.gov/content/executiveorders/ExecutiveOrders/1549.pdf [cited 2021 Mar $26]$.

27. State of Texas. (2021). Executive order GA 34. https:/open.texas.gov/uploads/files/organization/opentexas/EO-GA-34-opening-Texasresponse-to-COVID-disaster-IMAGE-03-02-2021.pdf [cited 2021 Mar 26].

28. The New York Times [NY Times]. (2021). Coronavirus in the U.S.: latest map and case count. https://www.nytimes.com/interactive/2020/us/coronavirus-us-cases.html\#states. [cited 2021 Apr 17].

29. United States Centers for Disease Control and Prevention [CDC]. (2020). Flu vaccination coverage, United States, 2019-20 influenza season. https://www.cdc.gov/flu/fluvaxview/coverage-1920estimates.htm. [cited 2021 Mar 26].

30. United States Centers for Disease Control and Prevention [CDC]. (2021a). Different vaccines. https://www.cdc.gov/coronavirus/2019-ncov/vaccines/different-vaccines.html. [cited 2021 Mar 26].

31. United States Centers for Disease Control and Prevention [CDC]. (2021b). COVID data tracker. https://covid.cdc.gov/covid-data-tracker/\#vaccinations. [cited 2021 Apr 17].

32. United States Centers for Disease Control and Prevention [CDC]. (2021c). CDC issues first set of guidelines on how fully vaccinated people can visit safely with others. 
medRxiv preprint doi: https://doi.org/10.1101/2021.04.19.21255737; this version posted April 27, 2021. The copyright holder for this preprint (which was not certified by peer review) is the author/funder, who has granted medRxiv a license to display the preprint in perpetuity.

It is made available under a CC-BY 4.0 International license.

https://www.cdc.gov/media/releases/2021/p0308-vaccinated-guidelines.html. [cited 2021

$378 \quad$ Mar 26].

379 33. Wickham, H. (2016). ggplot2: elegant graphics for data analysis. Springer-Verlag, New

380 York, USA. https://ggplot2-book.org/. [cited 2021 Mar 26].

381 34. Wilensky U. NetLogo. (1999). Center for Connected Learning and Computer-Based

382 Modeling, Northwestern University, Evanston, IL. http://ccl.northwestern.edu/netlogo/.

$383 \quad$ [cited 2021 Mar 26].

384 35. Wölfel R, Corman VM, Guggemos W, Sailmaier M, Zange S, Müller MA, Niemeyer D,

385 Jones TC, Vollmar P, Rothe C, Hoelscher M, Bleicker T, Brünink S, Schneider J, Ehmann R,

386 Zwirglmaier K, Drosten C, \& Wendtner C. (2020). Virological assessment hospitalized patients with COVID-2019. Nature 581:465-469. https://doi.org/10.1038/s41586-020-2196-

388

$\mathrm{X}$.

36. World Health Organization [WHO]. (2021). COVID-19 vaccines. https://www.who.int/emergencies/diseases/novel-coronavirus-2019/covid-19-vaccines. [cited 2021 Mar 26].

392

37. Yelin I, Katz R, Herzel E, Berman-Zilberstein T, Ben-Tov A, Kuint J, Gazit S, Patalon T,

393 Chodick G, \& Kishony R. (2021). Associations of the BNT162b2 COVID-19 vaccine

394 effectiveness with patient age and comorbidities. Preprint available at:

395 https://doi.org/10.1101/2021.03.16.21253686. 
medRxiv preprint doi: https://doi.org/10.1101/2021.04.19.21255737; this version posted April 27, 2021. The copyright holder for this preprint (which was not certified by peer review) is the author/funder, who has granted medRxiv a license to display the preprint in perpetuity.

\section{It is made available under a CC-BY 4.0 International license .}

\section{Tables}

\begin{tabular}{|c|c|c|c|}
\hline Parameter/Model Input & Purpose & Value(s) & Reference(s) \\
\hline \multicolumn{4}{|l|}{ Infectiousness parameters } \\
\hline \multicolumn{4}{|l|}{ Droplet count } \\
\hline (droplets/expectoration) ${ }^{\dagger}$ & Fixed value & $1.42 \mathrm{e}^{5}$ & Buonanno et al. 2020, Farthing \& Lanzas 2021 \\
\hline $\begin{array}{l}\text { Droplet spread angle }- \text { not } \\
\text { coughing }\left({ }^{\circ}\right)\end{array}$ & Fixed value & 63.5 & Kwon et al. 2012 \\
\hline $\begin{array}{l}\text { Droplet travel distance - not } \\
\text { coughing (m) }\end{array}$ & Fixed value & $0.55(0.068)^{\ddagger \S}$ & Das et al. 2020 \\
\hline $\begin{array}{l}\text { Vaccine-induced infectiousness } \\
\text { reduction (\%) }\end{array}$ & Within-group variation & $0,25,50,75$ & $\begin{array}{l}\text { Vaccination may reduce infectiousness of } \\
\text { asymptomatic individuals by as much as } 75 \% \text {, } \\
\text { but effects are unclear (Levine-Tiefenbrun et al. } \\
\qquad 2021 \text { ). }\end{array}$ \\
\hline Scenario environment and individ & l behavior inputs & & \\
\hline $\operatorname{Area}\left(\mathbf{m}^{2}\right)^{*}$ & Within-group variation & $36,81,225$ & - \\
\hline Expectoration height (m) & Fixed value & 1.7 & Fryar et al. 2018 \\
\hline Inhalation rate $\left(\mathrm{m}^{3} \mathrm{air} / \mathrm{min}\right)$ & Fixed value & 0.023 & Adams 1993 \\
\hline $\begin{array}{l}\text { Maximum people in a single 1- } \\
\text { m² patch (people) }^{2}\end{array}$ & Fixed value & 2 & - \\
\hline Number of asymptomatic & Fixed value & 1 & _- \\
\hline infectious individuals (people) & & & \\
\hline Scenario virion behavior inputs & Fixed value & & \\
\hline Virion count (virions/mL fluid) & Fixed value & $2.35 \mathrm{e}^{9}$ & Wölfel et al. 2020 \\
\hline Virion decay rate $(\% / \mathrm{min})$ & Fixed value & 1.05 & van Doremalen et al. 2020 \\
\hline
\end{tabular}


medRxiv preprint doi: https://doi.org/10.1101/2021.04.19.21255737; this version posted April 27, 2021. The copyright holder for this preprint (which was not certified by peer review) is the author/funder, who has granted medRxiv a license to display the preprint in perpetuity.

It is made available under a CC-BY 4.0 International license.

Virion infection risk $(\% /$ inhaled
Fixed value
6.24
Farthing \& Lanzas 2021

virion)

Scenario airflow inputs

Diffusion rate $\left(\mathrm{m}^{3} / \mathrm{min}\right)$

Fixed value

$1.5 \mathrm{e}^{-3}$

Castillo \& Weibel 2018

Forced airflow

Fixed value

off

Nonpharmaceutical

intervention scenarios
- Mask use (10\% exposure-

reduction efficacy), $2 \mathrm{~m}$

attempted social distancing

- $\quad$ Mask use $(25 \%$ exposure-

reduction efficacy), $2 \mathrm{~m}$

attempted social distancing

- $\quad$ Mask use $(50 \%$ exposure-

Between-group

comparison:

intervention

combinations

Within-group

variation: mask

efficacy

- $\quad$ Mask use (25\% exposure- reduction efficacy), $2 \mathrm{~m}$

attempted social distancing

- $\quad$ Mask use (10\% exposure-

masks to prevent exposure to infectious media.

reduction efficacy), no attempted Cloth mask efficacy is highly variable (O'kelly et al. 2020).

reduction efficacy), no attempted

social distancing

- Mask use (50\% exposure-

reduction efficacy), no attempted

social distancing

- No nonpharmaceutical

interventions 
medRxiv preprint doi: https://doi.org/10.1101/2021.04.19.21255737; this version posted April 27, 2021. The copyright holder for this preprint (which was not certified by peer review) is the author/funder, who has granted medRxiv a license to display the preprint in perpetuity.

It is made available under a CC-BY 4.0 International license .

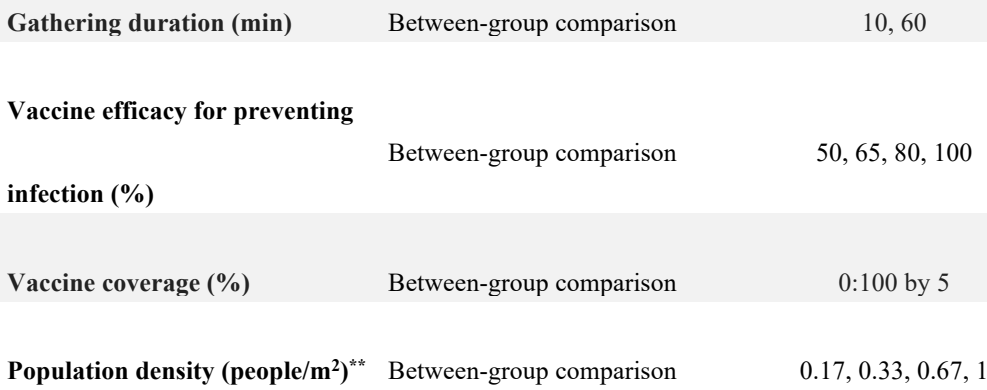

398 Table 1. Model parameter and scenario-specific input descriptions for transmission simulations.

399 *All simulated worlds were square-shaped. "The Purpose column describes why the parameter or

400 input was included as it relates to analyses. Specifically, "Fixed value" indicates that values are

401 unchanged across all simulations, and are thus irrelevant for analyses. "Between-group

402 comparison" indicates that levels were used in factorial combinations for data aggregation and

403 reporting. "Within-group variation" indicates that different levels were included to increase the

404 variation in simulation results, and by doing so increase model realism. ${ }^{\dagger}$ Based on linear

405 modeling described in Appendix S2 of Farthing \& Lanzas (2021), this value equates to 142

406 quanta/hr, the average quanta emission rate for asymptomatic people calculated by Buonanno et

407 al. (2020). ${ }^{\ddagger}$ Standard deviation is given in parentheses. ${ }^{\S}$ Das et al. (2020) estimated the average

408 travel distance of a 100-micrometer droplet expelled from a height of $1.7 \mathrm{~m}$ at a velocity of 0.5

$409 \mathrm{~m} / \mathrm{s}$ to be $0.55 \mathrm{~m}$. They also found that the majority of $100-\mu \mathrm{m}$ droplets will fall $0.55-2.35 \mathrm{~m}$

410 away from the expelling individual, depending on initial velocity, but droplets may settle up to

$4113.2 \mathrm{~m}$ away very rarely. A random draw of 10,000,000 samples from a log-normal distribution

412 parameterized using $1.7-\mathrm{m}$ and $0.2095-\mathrm{m}$ droplet spread distance mean and standard deviation

413 values, respectively, generated a distribution in line with this finding. The standard deviation we

414 use in simulations for non-coughing expectoration is proportionate to the one used in this random

415 draw. ${ }^{* *}$ Instead of specifying a fixed number of individuals in simulations, we scaled the

416 simulated population with world size. 
medRxiv preprint doi: https://doi.org/10.1101/2021.04.19.21255737; this version posted April 27, 2021. The copyright holder for this preprint (which was not certified by peer review) is the author/funder, who has granted medRxiv a license to display the preprint in perpetuity.

\section{It is made available under a CC-BY 4.0 International license .}

\begin{tabular}{lc}
\hline Covariate & Value(s) \\
\hline Gathering duration & 60 min \\
Intervention level & $\bullet \quad$ cloth face masks \& 2-m social distancing \& vaccination \\
& $\bullet \quad$ vaccination only \\
Vaccine coverage & $0: 1$ by 0.1 \\
Vaccine efficacy & $0.6,0.8$ \\
\hline
\end{tabular}

418 Table 2. Covariate values used for prediction in our example.

419

\begin{tabular}{|c|c|c|}
\hline Coefficient & Estimate & $p$ \\
\hline Intercept & $-3.786(-3.857,-3.716)$ & - \\
\hline$\phi$ & $28.899(28.336,29.462)$ & - \\
\hline Gathering duration (min) & $0.012(0.011,0.012)$ & $<0.001$ \\
\hline \multicolumn{3}{|l|}{ Intervention level } \\
\hline Cloth face masks \& 2-m social distancing \& vaccination* & $0(0,0)$ & - \\
\hline Cloth face masks \& vaccination & $0.761(0.737,0.785)$ & $<0.001$ \\
\hline Vaccination only & $0.889(0.866,0.913)$ & $<0.001$ \\
\hline Vaccine coverage & $0.783(0.660,0.905)$ & $<0.001$ \\
\hline Vaccine efficacy & $0.385(0.297,0.472)$ & $<0.001$ \\
\hline Vaccine coverage $X$ Vaccine efficacy & $-2.652(-2.816,-2.487)$ & $<0.001$ \\
\hline
\end{tabular}

Table 3. Logit scale estimates associated with 1-unit increases in covariate values given by our

421 beta-regression model. Wald 95\% confidence intervals are given in parentheses. ${ }^{*}$ This is the

422 reference level used to establish a baseline for binary dummy variables. 
medRxiv preprint doi: https://doi.org/10.1101/2021.04.19.21255737; this version posted April 27, 2021. The copyright holder for this preprint (which was not certified by peer review) is the author/funder, who has granted medRxiv a license to display the preprint in perpetuity.

It is made available under a CC-BY 4.0 International license .

\section{$425 \quad$ Figures}

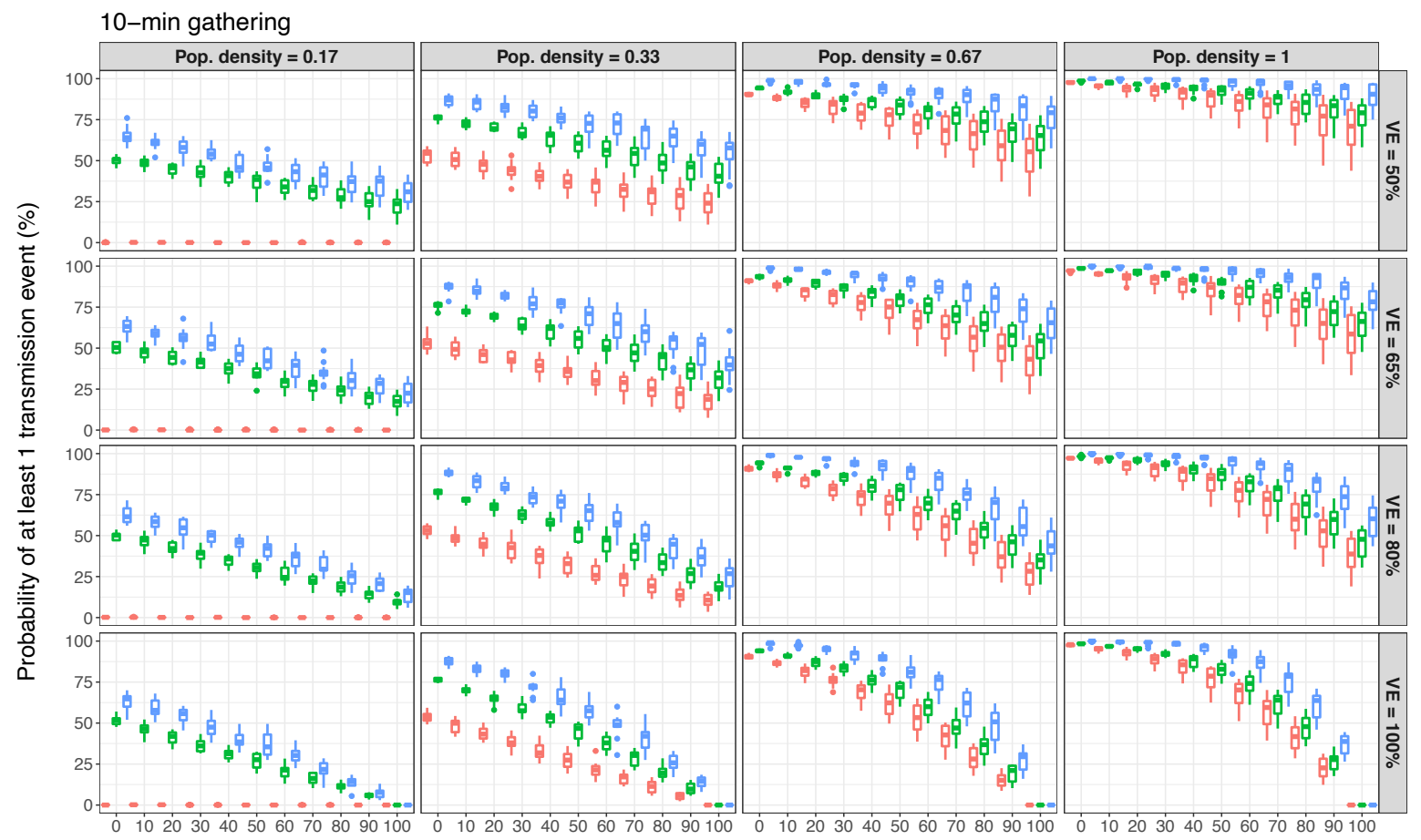

60-min gathering

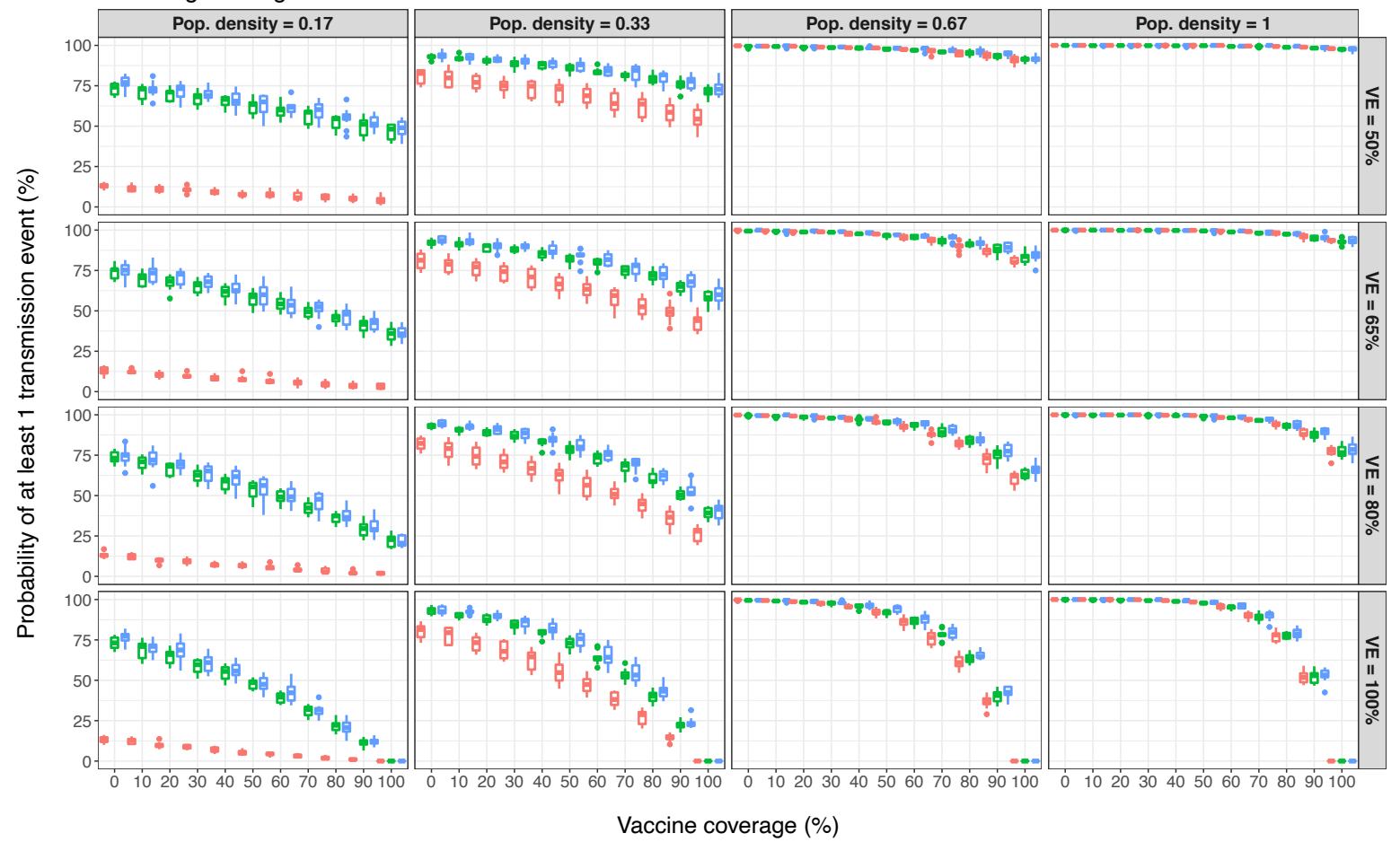

Additional interventions? 官 cloth face masks \& 2-m social distancing 
medRxiv preprint doi: https://doi.org/10.1101/2021.04.19.21255737; this version posted April 27, 2021. The copyright holder for this preprint (which was not certified by peer review) is the author/funder, who has granted medRxiv a license to display the preprint in perpetuity.

It is made available under a CC-BY 4.0 International license.

427 Figure 1. At low population densities and gathering duration limits, nonpharmaceutical

428 interventions to prevent infection and elevated vaccination rates consistently decrease the

429 probability of observing $\geq 1$ successful SARS-CoV-2 transmission events in simulations. 
medRxiv preprint doi: https://doi.org/10.1101/2021.04.19.21255737; this version posted April 27, 2021. The copyright holder for this preprint (which was not certified by peer review) is the author/funder, who has granted medRxiv a license to display the preprint in perpetuity.

It is made available under a CC-BY 4.0 International license .
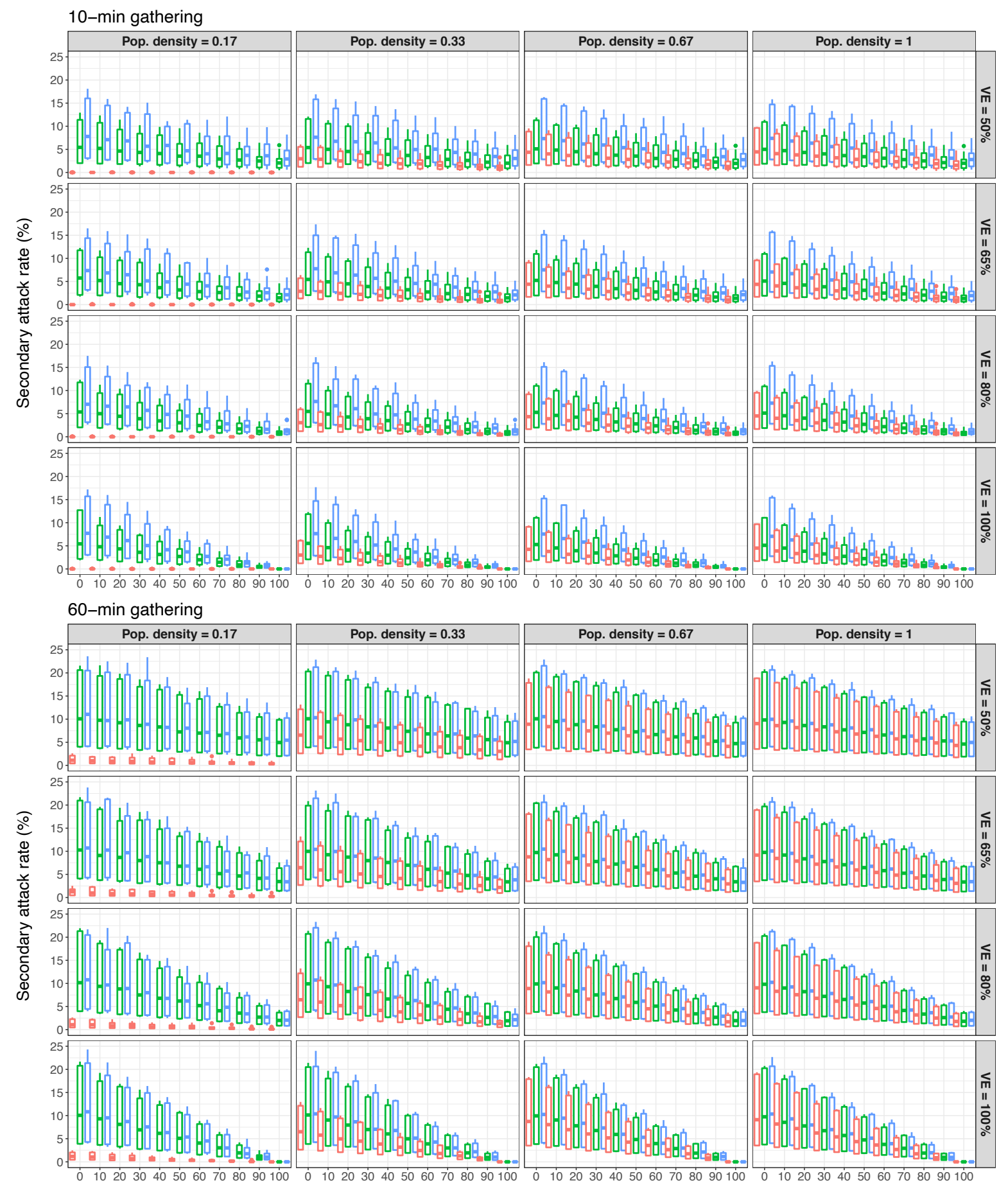

Vaccine coverage (\%)

Additional interventions? 追 cloth face masks \& 2-m social distancing

431 Figure 2. Mean secondary attack rates in simulations indicate substantial variability in risk. 
medRxiv preprint doi: https://doi.org/10.1101/2021.04.19.21255737; this version posted April 27, 2021. The copyright holder for this preprint (which was not certified by peer review) is the author/funder, who has granted medRxiv a license to display the preprint in perpetuity.

It is made available under a CC-BY 4.0 International license .

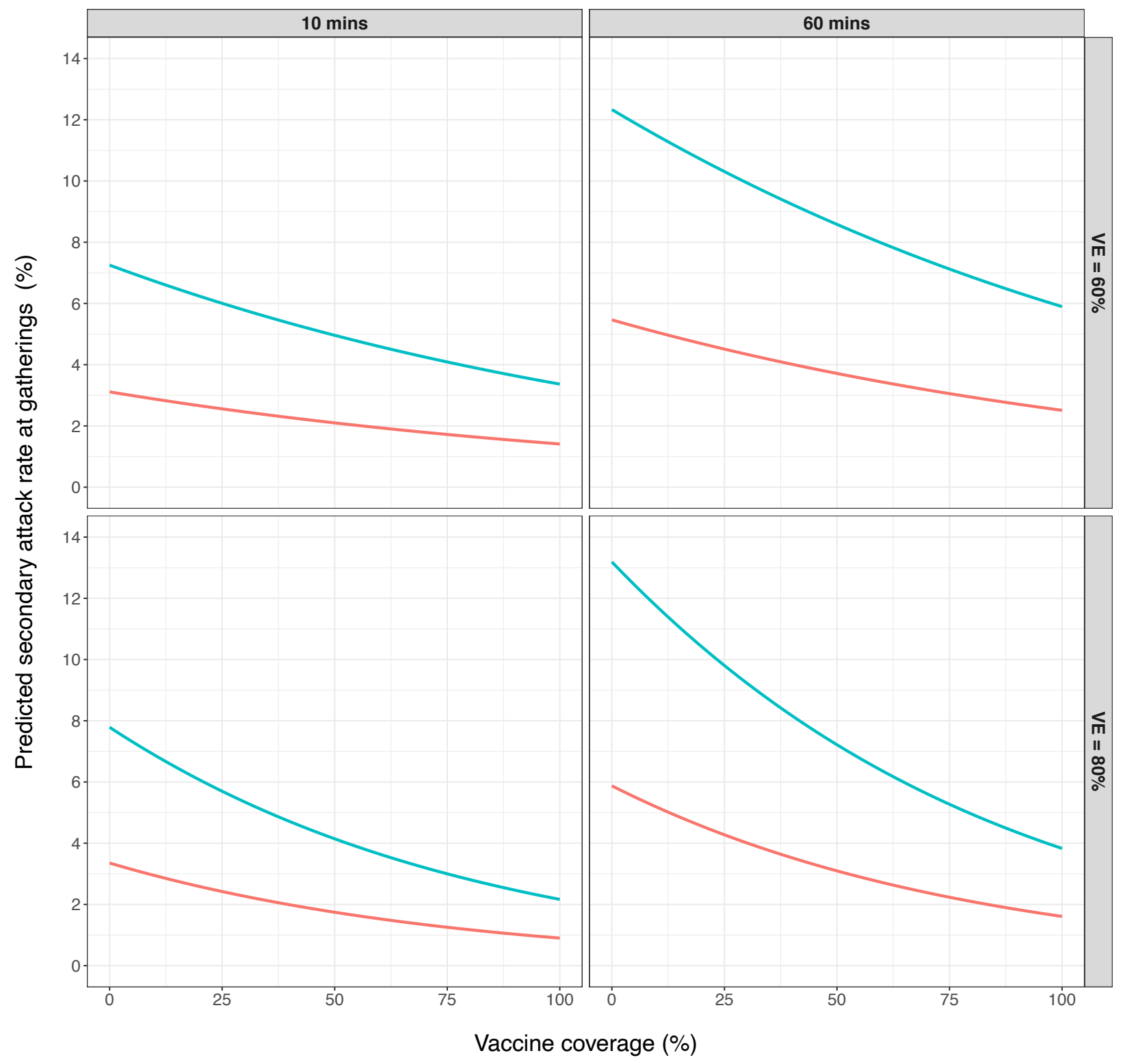

- Cloth face masks \& social distancing - No nonpharmaceutical interventions

433 Figure 3. Predicted secondary attack rates suggest that the combination of cloth face masks and

434 2-m social distancing during indoor gatherings of varying durations consistently reduces

435 secondary attack rates by $55-58 \%$. This effect was only modeled for vaccine efficacies of $60 \%$

436 and $80 \%$.

437 
medRxiv preprint doi: https://doi.org/10.1101/2021.04.19.21255737; this version posted April 27, 2021. The copyright holder for this preprint (which was not certified by peer review) is the author/funder, who has granted medRxiv a license to display the preprint in perpetuity.

It is made available under a CC-BY 4.0 International license.

a) 10 people gathering for 60 minutes
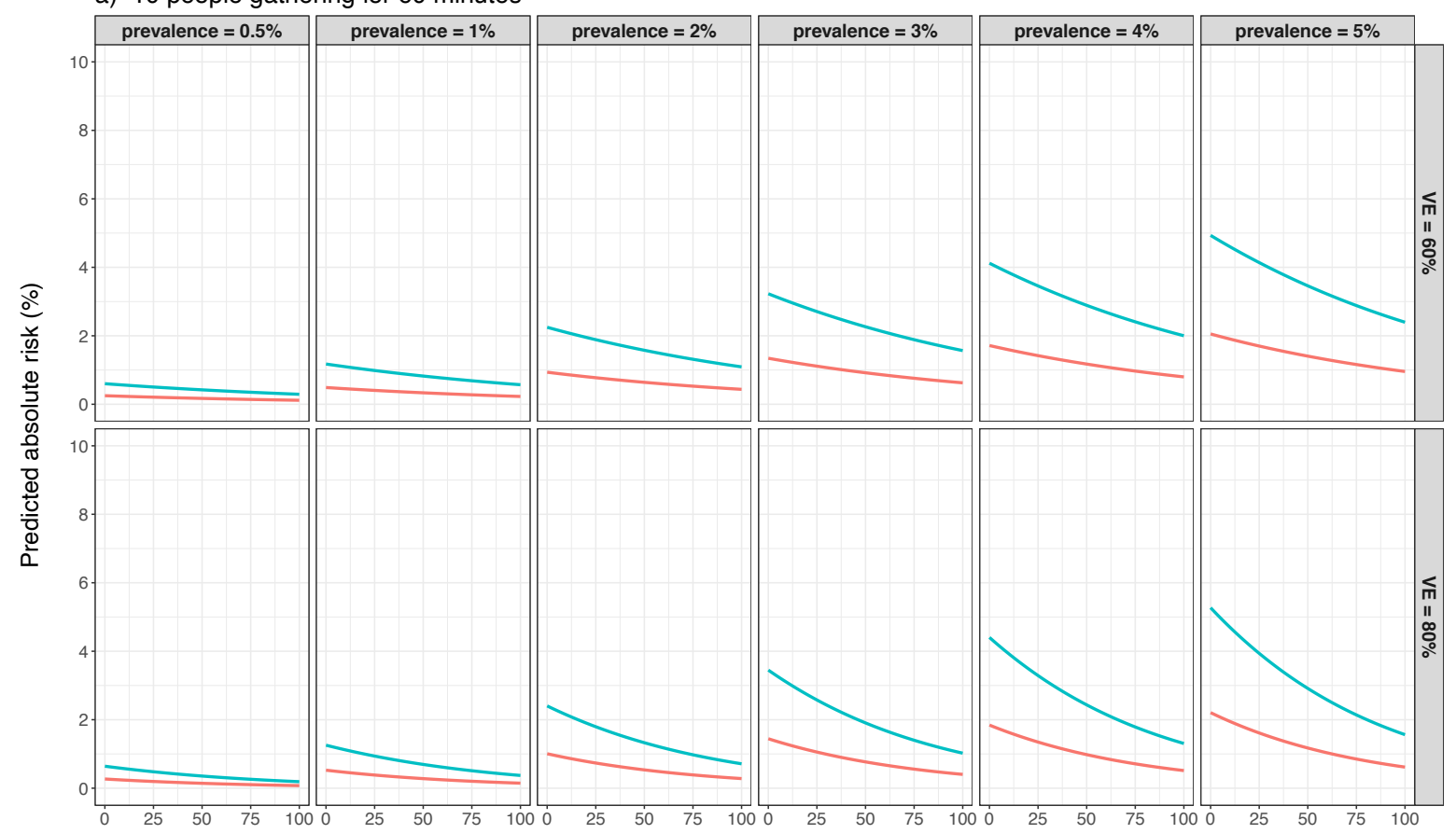

b) 20 people gathering for 60 minutes

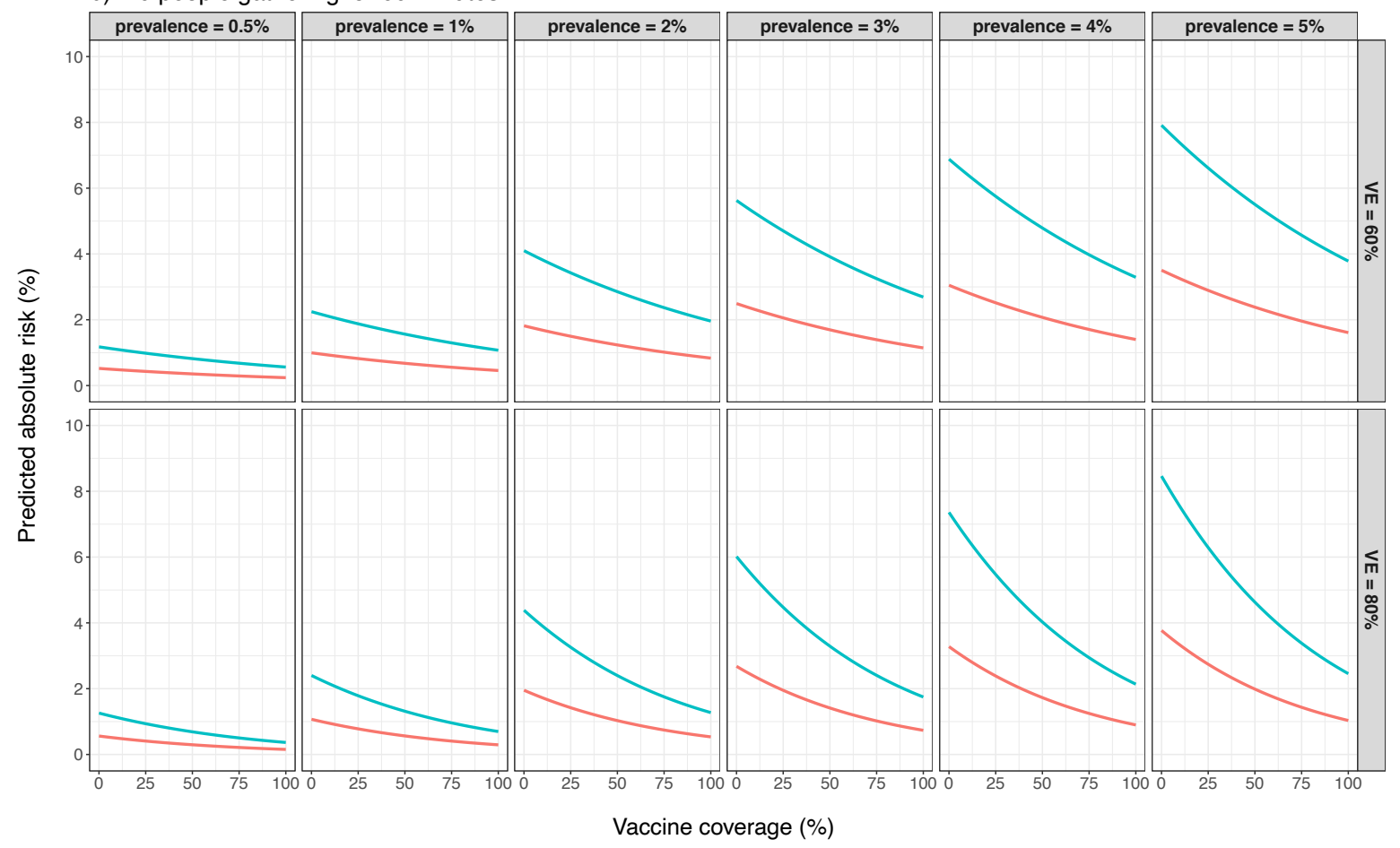

- Cloth face masks \& social distancing - No nonpharmaceutical interventions

439 Figure 4. Estimated absolute risk of being infected with SARS-CoV-2 during 60-minute 
medRxiv preprint doi: https://doi.org/10.1101/2021.04.19.21255737; this version posted April 27, 2021. The copyright holder for this preprint (which was not certified by peer review) is the author/funder, who has granted medRxiv a license to display the preprint in perpetuity.

It is made available under a CC-BY 4.0 International license.

440 gatherings of varied sizes. Estimates were obtained by plugging Figure 3 predictions into

441 Equation 3 with fixed COVID-19 prevalence and n values. a) Absolute risk of SARS-CoV-2

442 transmission given that 10 people attend the gathering. b) Absolute risk of SARS-CoV-2

443 transmission given that 20 people attend the gathering. 